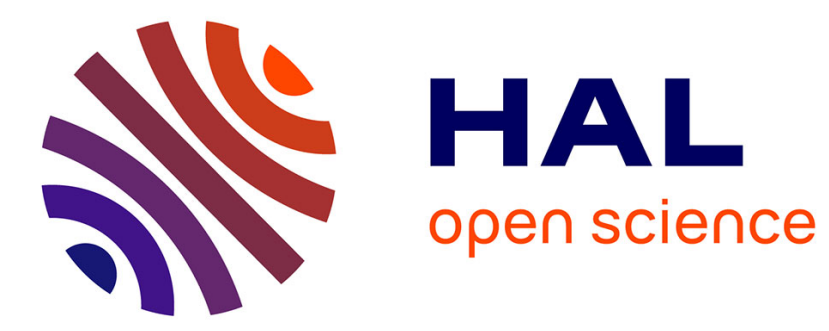

\title{
The Influence of Glass Composition on Iodine Solubility
} Maria Rita Cicconi, Eric Pili, Lucie Grousset, Daniel R. Neuville

\section{To cite this version:}

Maria Rita Cicconi, Eric Pili, Lucie Grousset, Daniel R. Neuville. The Influence of Glass Composition on Iodine Solubility. MRS Advances, 2019, 4 (17-18), pp.971-979. 10.1557/adv.2018.665 . hal02989644

\section{HAL Id: hal-02989644 \\ https://hal.science/hal-02989644}

Submitted on 26 Apr 2021

HAL is a multi-disciplinary open access archive for the deposit and dissemination of scientific research documents, whether they are published or not. The documents may come from teaching and research institutions in France or abroad, or from public or private research centers.
L'archive ouverte pluridisciplinaire HAL, est destinée au dépôt et à la diffusion de documents scientifiques de niveau recherche, publiés ou non, émanant des établissements d'enseignement et de recherche français ou étrangers, des laboratoires publics ou privés. 


\section{R S Advances}

The Influence of Glass Composition on Iodine Solubility

\begin{tabular}{|r|l|}
\hline Journal: & MRS Advances \\
\hline Manuscript ID & Draft \\
\hline Manuscript Type: & Regular Article \\
\hline Author: & n/a \\
\hline Complete List of Authors: & $\begin{array}{l}\text { Cicconi, Maria Rita; Institut de Physique du Globe de Paris, } \\
\text { Géomatériaux } \\
\text { Pili, Eric; CEA DAM Ile de France } \\
\text { Grousset, Lucie; Institut de Physique du Globe de Paris, Géomatériaux } \\
\text { Neuville, Daniel; Institut de Physique du Globe de Paris, Géomatériaux }\end{array}$ \\
\hline Keywords: & $\begin{array}{l}\text { glass, Raman spectroscopy, differential thermal analysis (DTA), hot } \\
\text { isostatic pressing (HIP) }\end{array}$ \\
\hline &
\end{tabular}




\title{
The Influence of Glass Composition on Iodine Solubility
}

\author{
Maria Rita Cicconi ${ }^{1}$, Eric Pili ${ }^{2}$, Lucie Grousset ${ }^{1}$, Daniel R. Neuville ${ }^{1}$ \\ ${ }^{1}$ Institut de Physique du Globe de Paris, Géomatériaux, CNRS-UMR7154, Sorbonne Paris Cité, 1 rue Jussieu 75005 Paris cedex 05, France \\ ${ }^{2}$ CEA, DAM, DIF, F-91297 Arpajon, France
}

\begin{abstract}
Two glass series in the ternary systems $\mathrm{K}_{2} \mathrm{O}-\mathrm{B}_{2} \mathrm{O}_{3}-\mathrm{SiO}_{2}(\mathrm{KBS})$ and $\mathrm{Na}_{2} \mathrm{O}_{-} \mathrm{B}_{2} \mathrm{O}_{3}-\mathrm{SiO}_{2}$ (NBS) were studied in order to identify the main factors influencing the solubility of iodine. We established that iodine incorporation is strongly linked to the bulk chemistry, i.e. the $\mathrm{SiO}_{2} /\left(\mathrm{B}_{2} \mathrm{O}_{3}+\mathrm{SiO}_{2}\right)$ molar ratio, and to the physical properties of the glasses, and we assessed three different solubility limits. Iodine in Si-rich glasses has a low solubility $(\leq 1 \mathrm{~mol} \%$ I) regardless of the alkali ion present. On the contrary, in B-rich glasses, the solubility is five times higher than in Si-rich glasses for Na-glasses, and more than six times higher for K-glasses. The strong dependence of iodine solubility on the bulk chemistry is related to the adaptability of the glass network. Furthermore, our data suggest that iodine is stable with different redox states in the glasses here analysed.
\end{abstract}

\section{INTRODUCTION}

Iodine, the heaviest stable halogen element, benefitted from relatively few studies on its solubility in glass matrices compared to the lighter halogens [1]. However, the incorporation, dissolution and mobility of this ion is very important in many fields, ranging from Materials and Earth Sciences to Waste management. Iodine occurs in nature as iodide $\left(\mathrm{I}^{-}\right)$, as the oxyanion iodate $\left(\mathrm{IO}_{3}{ }^{-}\right)$and rarely as elemental $\mathrm{I}\left(\mathrm{I}_{2}\right)$, respectively with oxidation states $-\mathrm{I},+\mathrm{V}$ and 0 .

The radioisotope ${ }^{129} \mathrm{I}$ is of particular concern because it will be the main contributor to the radioactivity released by a geological repository site for nuclear wastes [2]. Furthermore, the iodine-xenon 131, 133, 135 decay chains are particularly important in the framework of the verification of the Comprehensive nuclear-Test-Ban Treaty (CTBT). Indeed, atmospheric radioxenon monitoring constitutes an important mean for the detection of underground nuclear explosions after transport to the subsurface [3-5]. While the xenon source term in the nuclear cavity can be calculated, uncertainties persist regarding to what extend iodine may be trapped in magma inside the nuclear cavity [6].

Previous studies of iodine were mainly focused on the determination of iodine oxidation state and local surrounding in borosilicate waste glasses, and in cementitious wasteforms e.g. [7-9] because the assessment of the valence state is quite important when dealing with radionuclide. Indeed, beside the redox state of the environment, also physical and chemical form of the elements (e.g. valence) could influence their mobilisation, diffusion and (re)distribution [10]. In order to understand the main factors influencing the solubility of iodine, we investigated glasses in the ternary system $\mathrm{K}_{2} \mathrm{O}-\mathrm{B}_{2} \mathrm{O}_{3}-\mathrm{SiO}_{2}(\mathrm{KBS})$, where the $\mathrm{SiO}_{2} /\left(\mathrm{B}_{2} \mathrm{O}_{3}+\mathrm{SiO}_{2}\right)$ molar ratio was varied from 1 to 0 . Data on I-bearing $\mathrm{Na}_{2} \mathrm{O}-\mathrm{B}_{2} \mathrm{O}_{3}-\mathrm{SiO}_{2}$ (NBS) glasses are reported for comparison. The influence of iodine incorporation on glass physical properties, and glass network is here investigated by Raman spectroscopy.

\section{EXPERIMENTAL}

The borosilicate glasses here investigated have a constant amount (20 mol\%) of potassium (or sodium) and a $\mathrm{SiO}_{2} /\left(\mathrm{B}_{2} \mathrm{O}_{3}+\mathrm{SiO}_{2}\right)$ molar ratio ranging from 1 to 0 , i.e., from $\mathrm{K}(\mathrm{Na})$-silicate to $\mathrm{K}(\mathrm{Na})$-borate glasses. All pristine glasses were synthesised in large batches from the appropriate amounts of oxide $\left(\mathrm{SiO}_{2}\right)$, carbonate $\left(\mathrm{K}_{2} \mathrm{CO}_{3}\right.$, or $\mathrm{Na}_{2} \mathrm{CO}_{3}$, ) and acid $\left(\mathrm{H}_{3} \mathrm{BO}_{3}\right)$, and melted between 950 and $1400{ }^{\circ} \mathrm{C}$ (as a function of the $\mathrm{SiO}_{2} /\left(\mathrm{B}_{2} \mathrm{O}_{3}+\mathrm{SiO}_{2}\right)$ molar ratio) for a few hours to obtain bubble-free glasses. Powdered pristine glass and iodine compounds ( $\mathrm{I}_{2}$ or alkali-I salts) were mixed by hand in an agate mortar. Batch of $300 \mathrm{mg}$ of the powdered mixtures were inserted in platinum capsules and welded to avoid iodine leakage during experiments. Syntheses were carried out in a hot isostatic press (HIP) at Institut de Physique du Globe de Paris. The HIP is a medium-pressure (up to 2000 bars) high-temperature (up to $2000{ }^{\circ} \mathrm{C}$ ) device. Experimental details are provided in [11]. Synthesis with solid $\mathrm{I}_{2}$ as starting material were all carried out at $1200 \mathrm{C}$ and 1500 bar. Synthesis with alkali-I salts $\left(\mathrm{KIO}_{3}\right.$ or $\left.\mathrm{NaIO}_{3}\right)$ as starting salts were carried out at different conditions of pressure and temperature, and for different holding times. Chemical compositions of both pristine and I-bearing glasses have been analysed with a Cameca SX100 electron microprobe (Table 1). Boron nitride $(\mathrm{BN})$ and copper iodide were used as boron and iodine standards respectively. Ten measurements per 
sample (at $15 \mathrm{keV}$ and $40 \mathrm{nA}$ ) were performed to obtain more representative values of boron and iodine contents. The average compositions, of KBS glasses, are reported in Table 1. Boron calibration was achieved with BN as a standard and boron's Ka absorption coefficients by the other elements were adjusted on the analysis of several borosilicate glasses with variable $\mathrm{B}_{2} \mathrm{O}_{3}$ content from 80 to 0 mol\%. Raman spectra were recorded at room temperature using a T64000 Jobin-Yvon ${ }^{\circledR}$ Triple-spectrometer set up with a confocal system, and a $1024 \mathrm{CCD}$ detector cooled by liquid nitrogen. A Coherent ${ }^{\circledR}$ laser 70C Argon, with a wavelength of $488.1 \mathrm{~nm}$, was used as excitation source providing $100 \mathrm{~mW}$ on the sample. All spectra were recorded between 16 and $1700 \mathrm{~cm}^{-1}$ with an integration time of $300 \mathrm{~s}$. Linear baseline subtraction and normalization to the total area were performed with LabSpec ${ }^{\circledR}$ software. Density measurements (Table 1$)$ were done at room temperature by Archimedean method, using toluene as the immersion fluid. Glass transition temperatures (Tg) were determined by Differential Thermal Analysis (DTA) with a Setaram 96 Line Evo apparatus. A blank analysis was performed before sample analysis to corrected data from background signal. Temperature was increased with a rate of $5{ }^{\circ} \mathrm{C} / \mathrm{min}$ and Tg was quantified by tangential method. All samples are labelled according the composition and iodine contents: NBSx and KBSx refer to pristine sodium/potassium borosilicate glasses where $\mathrm{x}$ represents the $\mathrm{SiO}_{2}$ molar content. KBSx.y refers to iodine-bearing glasses doped with $\mathrm{K}(\mathrm{Na}) \mathrm{IO}_{3}$, where $\mathrm{x}$ represents the $\mathrm{SiO}_{2}$ molar content, and y the iodine molar content.

Table 1 - Analysed chemical composition (wt.\%) and properties of KBS glasses. Some of the glasses in the NBSx $+\mathrm{I}_{2}$ series are reported for comparison (from [11]).

\begin{tabular}{|c|c|c|c|c|c|c|c|c|}
\hline Sample & $\begin{array}{l}\text { salt } \\
\text { used }\end{array}$ & $\begin{array}{l}\text { starting } \\
\text { amount I } \\
(\mathrm{mol} \%)\end{array}$ & $\begin{array}{l}\mathrm{SiO}_{2} \\
\text { (wt.\%) }\end{array}$ & $\begin{array}{l}\mathrm{B}_{2} \mathrm{O}_{3} \\
(w t . \%)\end{array}$ & $\begin{array}{l}\mathrm{Na}_{2} \mathrm{O} \text { or } \\
\mathrm{K}_{2} \mathrm{O} \text { (wt.\%) }\end{array}$ & $\mathrm{I}(\mathrm{wt} \%)$ & $\begin{array}{l}\text { Density } \\
\left(\mathrm{g} / \mathrm{cm}^{3}\right)\end{array}$ & $\begin{array}{l}\mathrm{Tg} \\
(\mathrm{K})\end{array}$ \\
\hline \multicolumn{9}{|c|}{ pristine glasses } \\
\hline KBS80 & & & 72.37 & 0.00 & 25.99 & & $2.398(1)$ & 718 \\
\hline KBS60 & & & 68.89 & 15.14 & 16.80 & & $2.442(2)$ & 920 \\
\hline KBS40 & & & 33.86 & 48.96 & 19.58 & & $2.224(4)$ & 578 \\
\hline KBS20 & & & 14.76 & 66.86 & 22.66 & & $2.189(3)$ & 605 \\
\hline KBS00 & & & 0.00 & 75.22 & 24.67 & & $2.109(4)$ & 536 \\
\hline \multicolumn{9}{|c|}{$\mathrm{KIO}_{3}$ series: KBSx.y $\left(1500{ }^{\circ} \mathrm{C}, 1500\right.$ bar $)$} \\
\hline KBS80.1 & $\mathrm{KIO}_{3}$ & 2 & 68.23 & 0.00 & 22.27 & 1.90 & $2.396(2)$ & \\
\hline KBS60.03 & $\mathrm{KIO}_{3}$ & 2 & 70.92 & 12.02 & 14.93 & 0.52 & $2.461(7)$ & \\
\hline KBS40.2 & $\mathrm{KIO}_{3}$ & 2 & 30.16 & 44.38 & 17.77 & 3.39 & $2.250(2)$ & \\
\hline KBS20.1 & $\mathrm{KIO}_{3}$ & 2 & 14.15 & 61.66 & 21.34 & 2.01 & $2.214(3)$ & 592 \\
\hline KBS00.1 & $\mathrm{KIO}_{3}$ & 2 & 0 & 74.79 & 22.67 & 2.26 & $2.118(7)$ & \\
\hline \multicolumn{9}{|c|}{$\mathrm{I}_{2}$ series: $\mathrm{KBSx}+\mathrm{I}_{2}\left(1200^{\circ} \mathrm{C}, 1500\right.$ bar $)$} \\
\hline $\mathrm{KBS} 80+\mathrm{I}_{2}$ & $\mathrm{I}_{2}$ & 2 & 71.41 & 3.28 & 24.56 & 1.38 & $2.400(1)$ & \\
\hline $\mathrm{KBS} 80+\mathrm{I}_{2}$ & $\mathrm{I}_{2}$ & 9 & 74.10 & 1.85 & 20.38 & 1.21 & $2.376(1)$ & \\
\hline $\mathrm{NBS} 80+\mathrm{I}_{2}$ & $\mathrm{I}_{2}$ & 2 & 78.95 & 2.66 & 18.85 & 2.22 & $2.373(1)$ & 730 \\
\hline $\mathrm{NBS} 80+\mathrm{I}_{2}$ & $\mathrm{I}_{2}$ & 10 & 76.62 & 2.11 & 18.48 & 2.28 & $2.316(1)$ & \\
\hline $\mathrm{NBS} 80+\mathrm{I}_{2}$ & $\mathrm{I}_{2}$ & 18.2 & 70.42 & 4.93 & 23.06 & 1.64 & $2.468(11)$ & \\
\hline $\mathrm{NBS} 60+\mathrm{I}_{2}$ & $\mathrm{I}_{2}$ & 9.5 & 59.51 & 22.74 & 14.98 & 1.88 & $2.495(1)$ & \\
\hline $\mathrm{NBS} 60+\mathrm{I}_{2}$ & $\mathrm{I}_{2}$ & 18.1 & 63.70 & 22.18 & 9.13 & 1.64 & $2.460(1)$ & \\
\hline $\mathrm{KBS} 20+\mathrm{I}_{2}$ & $\mathrm{I}_{2}$ & 2.1 & 13.90 & 61.14 & 21.18 & 4.12 & $2.206(1)$ & 593 \\
\hline $\mathrm{KBS} 20+\mathrm{I}_{2}$ & $\mathrm{I}_{2}$ & 9.5 & 14.57 & 62.95 & 19.15 & 4.51 & $2.201(1)$ & 675 \\
\hline $\mathrm{KBS} 20+\mathrm{I}_{2}$ & $\mathrm{I}_{2}$ & 18.2 & 14.72 & 47.06 & 10.67 & 9.24 & $2.116(4)$ & \\
\hline $\mathrm{KBS} 20+\mathrm{I}_{2}$ & $\mathrm{I}_{2}$ & 26.7 & 16.27 & 49.70 & 8.11 & 8.75 & $2.090(1)$ & \\
\hline $\mathrm{NBS} 20+\mathrm{I}_{2}$ & $\mathrm{I}_{2}$ & 2 & 14.07 & 66.87 & 13.89 & 3.57 & $2.212(1)$ & 697 \\
\hline $\mathrm{NBS} 20+\mathrm{I}_{2}$ & $\mathrm{I}_{2}$ & 10.1 & 13.85 & 63.35 & 10.61 & 8.99 & $2.189(1)$ & 590 \\
\hline $\mathrm{NBS} 20+\mathrm{I}_{2}$ & $\mathrm{I}_{2}$ & 18 & 14.61 & 60.69 & 6.54 & 7.09 & $2.080(7)$ & 513 \\
\hline $\mathrm{KBS} 80+\mathrm{I}_{2}$ & $\mathrm{I}_{2}$ & 2 & 0.03 & 73.78 & 22.39 & 3.47 & $2.133(1)$ & \\
\hline $\mathrm{KBS} 80+\mathrm{I}_{2}$ & $\mathrm{I}_{2}$ & 10 & 0.05 & 62.98 & 19.33 & 16.26 & $2.212(1)$ & \\
\hline $\mathrm{NBS} 00+\mathrm{I}_{2}$ & $\mathrm{I}_{2}$ & 2 & 0.07 & 82.33 & 11.25 & 4.17 & $2.100(7)$ & 499 \\
\hline
\end{tabular}

$\S$ volumetric mass density 
Page 3 of 6

\section{RESULTS AND DISCUSSION}

Physical and thermal properties have been determined for all pristine glasses. Figures $1 \mathrm{~A}$ and $\mathrm{B}$ show the evolutions of the volumetric mass density (density for short) and glass transition temperature (Tg), in relation with the $\mathrm{SiO}_{2} /\left(\mathrm{B}_{2} \mathrm{O}_{3}+\mathrm{SiO}_{2}\right)$ molar ratio for the pristine glasses synthetized under pressure. Density and Tg increase smoothly until $60 \mathrm{~mol} \%$ of Si is substituted for B, with differences up to $20-22 \%$ in both properties, in agreement with published data in the NBS system [12]. When Si is substituted for B, the properties of KBS glasses follow a similar trend, although more irregularly.

The addition of iodine, in the two ternary systems, does not change the general trend, with both Tg and density increasing until a $\mathrm{SiO}_{2} /\left(\mathrm{B}_{2} \mathrm{O}_{3}+\mathrm{SiO}_{2}\right)$ molar ratio equal to 0.75 for NBS glasses, and 0.87 for KBS glasses. I-bearing glasses have slightly higher density values for all compositions, with the B-rich ones being $\sim 2 \%$ denser. Glass transition temperature values for the I-bearing NBS glasses are reported in Figure 1B, and they are always lower compared to the I-free glasses with variations of Tg up to $10 \%$ (data from [11]). Sample KBS60 has an anomalous higher Tg, and is partially out of trend. This glass has a lower potassium content, and a $\mathrm{K}_{2} \mathrm{O} /\left(\mathrm{SiO}_{2}+\mathrm{B}_{2} \mathrm{O}_{3}\right) \mathrm{molar}$ ratio of 0.13 , thus providing a glass transition temperature higher than $900 \mathrm{~K}$.
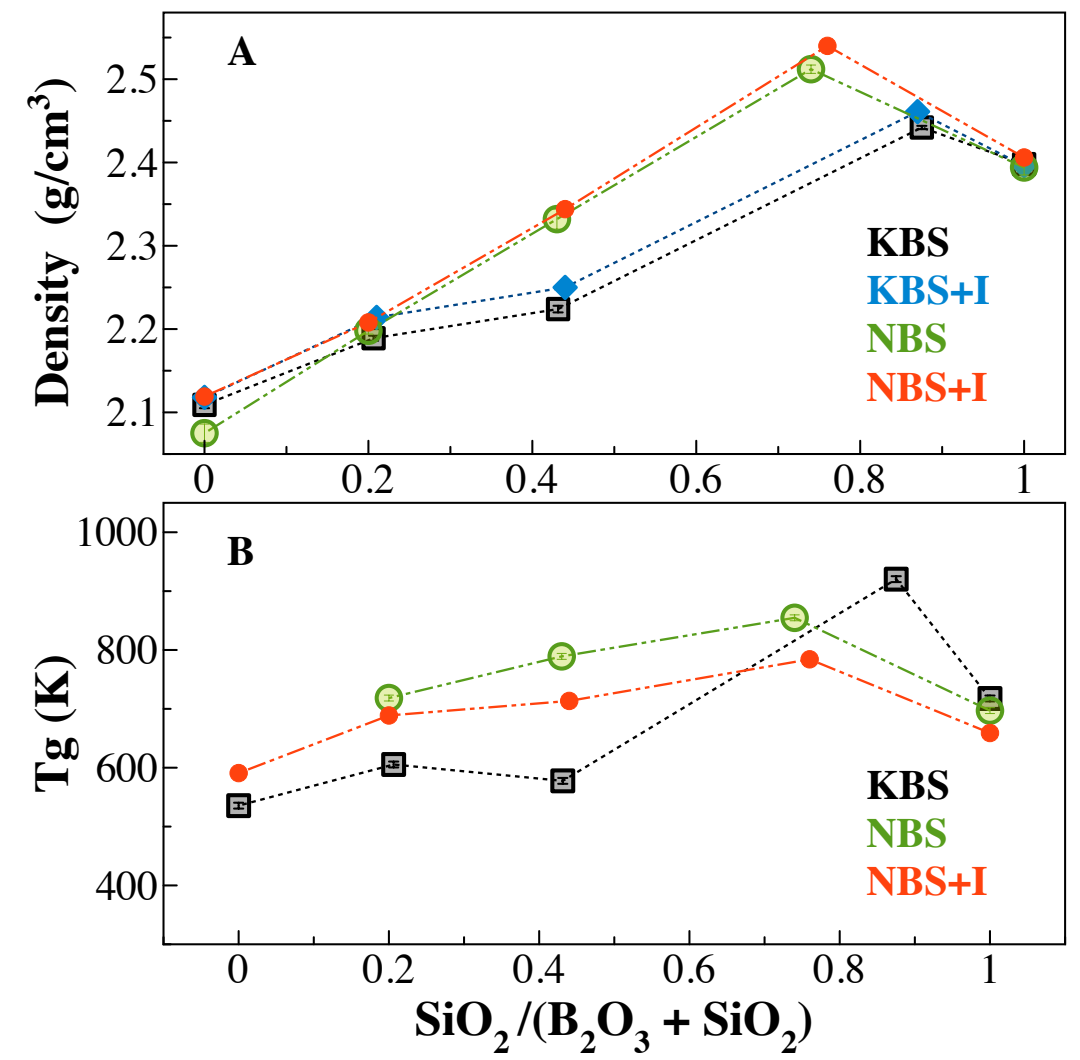

Figure 1 - A, B) Volumetric mass density $\left(\mathrm{g} / \mathrm{cm}^{3}\right)$ and glass transition temperature $(\mathrm{Tg}, \mathrm{K})$ vs. the $\mathrm{SiO}_{2} /\left(\mathrm{B}_{2} \mathrm{O}_{3}+\mathrm{SiO}_{2}\right)$ molar ratios, for pristine $\mathrm{KBS}$ and $\mathrm{NBS}$ compositions, and iodine-bearing glasses (+I). Errors within the points. Lines are guide for the eyes.

The influence of synthesis conditions (pressure $\mathrm{P}$, temperature $\mathrm{T}$ ) on iodine solubility is shown in Figure 2. Glasses doped with $\mathrm{KIO}_{3}$ were synthesised under various $\mathrm{P}, \mathrm{T}$ conditions and for different holding times to verify the attainment of equilibria, and the influence of pressure on iodine solubility. Glasses in the NBS system synthesised at $1500{ }^{\circ} \mathrm{C}$ and 1500 bar are reported for comparison (black solid symbols; data from [11]).

Synthesis at the lowest $\mathrm{T}$ and $\mathrm{P}$ were held for almost 19 hours, whereas the synthesis at $1500{ }^{\circ} \mathrm{C}$ and 1500 bar were held for 7 hours. For all I-bearing KBS glasses there is a general trend, with higher iodine solubility in boron-rich compositions (dashed line in Figure 2). The iodine content dissolved into the glasses did not vary too much between the different conditions of pressure, temperature and holding time, indicating that equilibrium was attained for all experiments. Depending on the $\mathrm{SiO}_{2} /\left(\mathrm{B}_{2} \mathrm{O}_{3}+\mathrm{SiO}_{2}\right)$ molar ratio the amount of iodine incorporated within the KBS glass network varies from $0.27(1)$ to $1.97(10) \mathrm{mol} \%$ with a maximum for the glasses with $\mathrm{SiO}_{2} /\left(\mathrm{B}_{2} \mathrm{O}_{3}+\mathrm{SiO}_{2}\right)$ ratio $\sim 0.45$. Interestingly, all samples with a nominal amount of $60 \mathrm{~mol} \% \mathrm{SiO}_{2}(\mathrm{KBS} 60)$ have extremely low amount of iodine incorporated into the glasses. 


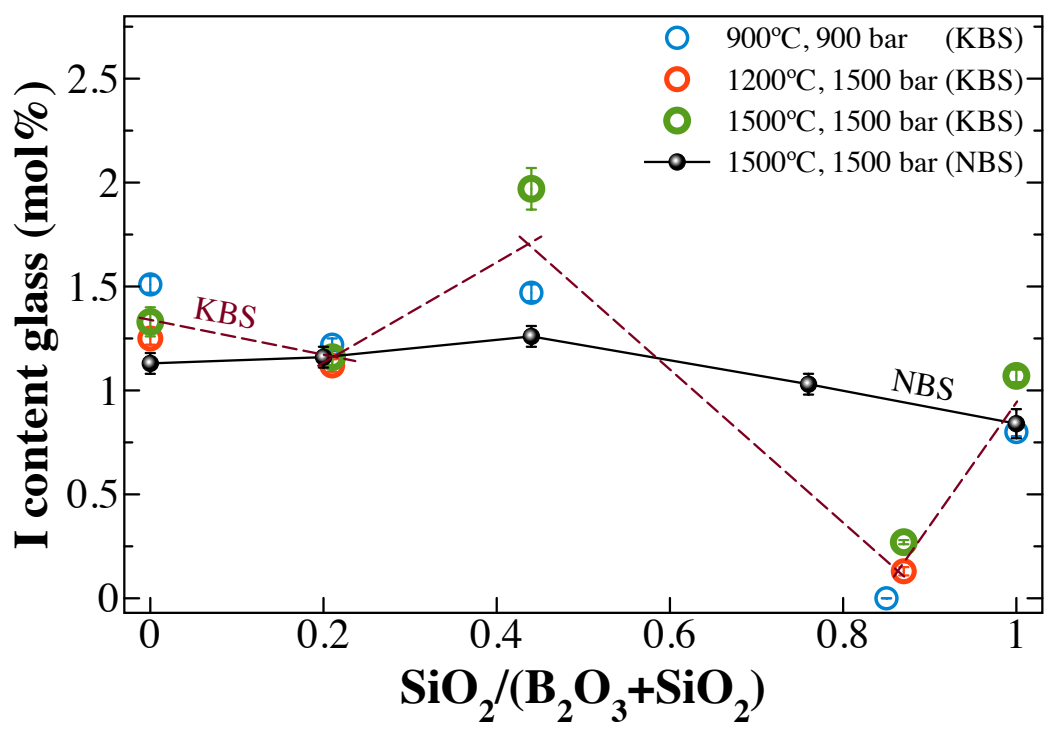

Figure 2 - Iodine content (as mol\%) incorporated in the different KBS glass compositions, depending on the synthesis conditions. I-bearing NBS glasses are reported for comparison (black solid line and symbols; data from [11]). Dashed line follows the general trend of KBS glasses. Lines are only guides for the eyes.

In order to establish the solubility limit of iodine in glasses, the two glass series were doped with increasing amounts of solid $\mathrm{I}_{2}$ in the Pt capsules. In Figure 3, the nominal (starting) amount of iodine added is reported for the different compositions, either in the KBS or in the NBS systems, against the I content measured in the final synthesised glasses. Regardless the starting amount, iodine content for $\mathrm{B}_{2} \mathrm{O}_{3}$-rich samples is always higher than for the $\mathrm{SiO}_{2}$-rich ones. Furthermore, $\mathrm{Na} \mathrm{SiO}_{2}$-rich glasses, with iodine contents greater than 5 mol\%, were frequently partially crystallised and/or heterogeneous.

The highest amount of iodine is incorporated in glasses with $\mathrm{SiO}_{2} /\left(\mathrm{B}_{2} \mathrm{O}_{3}+\mathrm{SiO}_{2}\right)$ molar ratio 0.20 (NBS20, and KBS20). Potassium-glasses have higher ability to dissolve iodine, with a solubility limit established around 6.5mol\%. The B-end member (KBS00) in the potassium series retained up to $10 \mathrm{~mol} \% \mathrm{I}$, but the lack of further experiments does not allow to establish the solubility limit. $5 \mathrm{~mol} \%$ I represents the solubility limit for sodium B-rich glasses (NBS20) since higher doping levels did not produce any increase of iodine in the glass. $\mathrm{SiO}_{2}$-rich glasses were not able to incorporate more than $1 \mathrm{~mol} \% \mathrm{I}$, either in the KBS or in the NBS system (Figure 3 ).

Glasses with KBS60 composition are depleted in $\mathrm{K}_{2} \mathrm{O}$ and have extremely low content of dissolved iodine $(<0.3 \mathrm{~mol} \%)$, suggesting that alkali cations play a crucial role in enhancing iodine solubility.

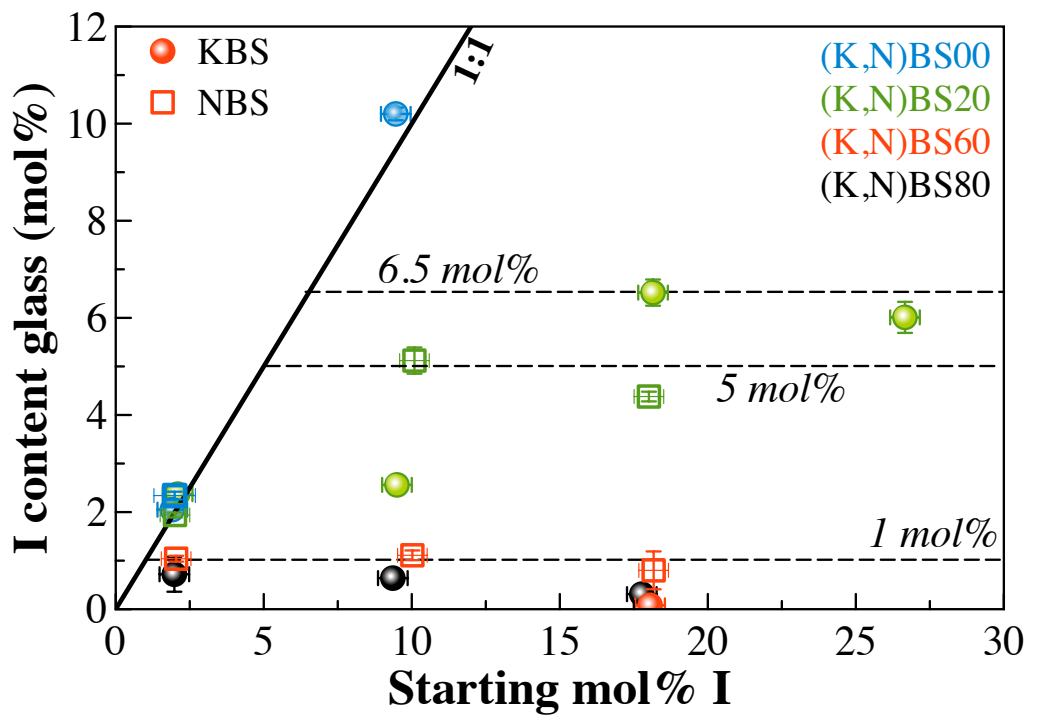

Figure 3 - Measured iodine content in the glasses as a function of the starting amount added, as solid $\mathrm{I}_{2}$. The solubility limits identified are reported as horizontal dashed lines.

Raman spectra for KBS glasses with $20 \mathrm{~mol} \% \mathrm{SiO}_{2}$ are shown in Figure 4, along with the corresponding iodine-bearing glasses. Spectra for NBS20 glasses are reported for comparison. All bands are broad and are typical of B-rich alkali-silicate glasses [12-13]. The vibrations related to Si-O-Si bending and Si-O stretching modes are weak and are, respectively, in the frequency regions below $600 \mathrm{~cm}^{-1}$ and between $850 \mathrm{~cm}^{-1}$ and $1250 \mathrm{~cm}^{-1}$. 
Iodine incorporation in those glasses induces three main variations (Figure 4): in the very low $\left(<250 \mathrm{~cm}^{-1}\right)$, in the intermediate $\left(650-900 \mathrm{~cm}^{-1}\right)$, and in the high $\left(1200-1600 \mathrm{~cm}^{-1}\right)$ frequency regions. The latter region contains vibrations associated to stretching of B$\mathrm{O}^{-}$bonds of both tri-fold and four-fold coordinated boron (respectively, $\mathrm{BO}_{3}$ and $\mathrm{BO}_{4}$ units). Upon iodine incorporation the integrated area of this region decreases by $\sim 17 \%$ (KBS20 sample containing $2.56(14) \mathrm{mol} \% \mathrm{I}$ ). The relatively narrow bands in the $650-900 \mathrm{~cm}^{-1}$ frequency region represent breathing vibrations of pentaborate rings $\left(\sim 770 \mathrm{~cm}^{-1}\right)$, and three corner-sharing $\mathrm{BO}_{3}$ rings $\left(\right.$ boroxol rings, $\left.\sim 805 \mathrm{~cm}^{-1}\right)$. Iodine incorporation induces a decrease of the bands associated with pentaborate rings $\left(770\right.$ and $\left.732 \mathrm{~cm}^{-1}\right)$, and a net increase of the boroxol at $\sim 805 \mathrm{~cm}^{-1}$ both in $\mathrm{Na}$ and $\mathrm{K}$ borosilicate glasses (Figure 4, vertical dashed line at $805 \mathrm{~cm}^{-1}$ ). In the very low frequency region $\left(<250 \mathrm{~cm}^{-1}\right)$ the rise of a broad shoulder around $110 \mathrm{~cm}^{-1}$ for I-bearing KBS samples, and a shift of the Boson peak toward lower frequencies can be observed. This additional contribution is clearly visible in the NBS20 glass containing $\sim 5 \mathrm{~mol} \%$ I (Figure 4, dashed line at $\left.109 \mathrm{~cm}^{-1}\right)$. Iodine incorporation in borosilicate glasses induces higher amounts of $\left[\mathrm{BO}_{3}\right]$-ring units compared to $\left[\mathrm{BO}_{4}\right]$. Usually, in alkali-B glasses, the stabilization of 4-fold coordinated boron units is due to an electron taken from $\mathrm{K}^{+}$(or $\mathrm{Na}^{+}$) ions. Therefore, the alkali cation provides local charge neutrality being adjacent to the negative $\mathrm{BO}_{4}^{-}$units [14].

Raman spectra of I-crystals identified the occurring of two main vibrational regions [11]: iodide crystalline compounds have the strongest bands in the very low frequency region $\left(25-250 \mathrm{~cm}^{-1}\right)$, whereas iodate crystalline compounds have their main vibrations in the region $650-850 \mathrm{~cm}^{-1}$. In iodine-bearing glasses, the increase of $\left[\mathrm{BO}_{3}\right]$ units, and the occurrence of the shoulder at very low frequencies, could be explained by considering $\mathrm{K}^{+}$ions being adjacent to $\mathrm{I}^{-}$ions. This implies the presence of iodide species, and, as previously suggested for NBS glasses and other borosilicate compositions [7-11-15] it likely results from the halogen local environment, where $\mathrm{I}^{-}$ ions are surrounded by alkali cations. On the other hand, the particularly high increase of the peak around $805 \mathrm{~cm}^{-1}$ could be explained by the presence of extra contributions related to iodate vibrations $<\mathrm{I}^{5+}-\mathrm{O}>$. Hence, the presence of additional contributions in the Raman spectra of I-bearing alkali borate glasses suggests the coexistence of iodine with different stable oxidation states.

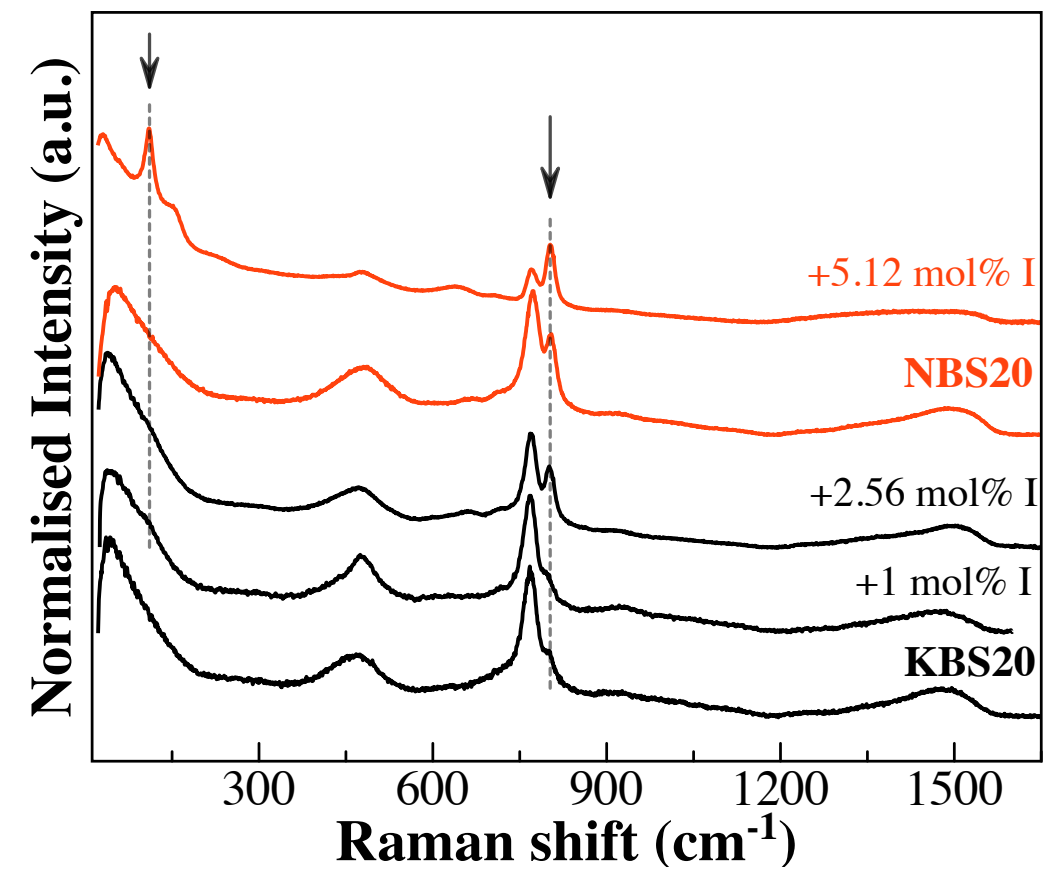

Figure 4 - Raman spectra of pristine glasses and I-bearing glasses. The dissolution of iodine in these glasses induces the appearance of two extra features, respectively around $109 \mathrm{~cm}^{-1}$ and $805 \mathrm{~cm}^{-1}$ (vertical dashed lines).

Based on the solubility study and on the Raman results we could speculatively say that the solubility of iodide species should be much higher than the solubility of iodate in borosilicate glasses. The stabilization of the reduced form is driven by the field strength of the alkali cation that will surround the halogen element in the first coordination shell, probably due to the larger continuous channels produced (percolation channels [16]).

\section{CONCLUSIONS}

Iodine incorporation in alkali borosilicate glasses is strongly affected by the bulk chemistry $\left(\mathrm{SiO}_{2} /\left(\mathrm{B}_{2} \mathrm{O}_{3}+\mathrm{SiO} 2\right)\right.$ ratio, alkali ion). Iodine solubility limits have been established for potassium borosilicate glasses and compared to that of sodium borosilicate glasses, as follows:

- $\sim 5 \mathrm{~mol} \% \mathrm{I}$ and $\sim 6.5 \mathrm{~mol} \% \mathrm{I}$, respectively for $\mathrm{B}_{2} \mathrm{O}_{3}$-rich glasses in the NBS and KBS systems;

$-\leq 1 \mathrm{~mol} \%$ I for Si-rich glasses, independently on the alkali cation.

Our results indicate that alkalis play a crucial role in enhancing iodine solubility. Most probably, elements with higher cation field strength (e.g. K) increases the incorporation of iodine because they induce larger continuous channels in the borosilicate glass network that might help iodine diffusion and dissolution. 
Raman spectroscopy, even if not an element specific technique, points to the presence of iodine with different stable valences within the glass network, confirming the versatility of this technique, and the potentiality to use it for other glass or glass/ceramic materials.

\section{ACKNOWLEDGMENTS}

This work was funded in the framework of a CEA-IPG Paris collaboration.

\section{References}

1. L. Grousset, E. Pili, \& D. R. Neuville, Incorporation et rôle des halogènes dans les silicates vitreux et fondus. Matériaux et Techniques, 103 (2015).

2. X. Hou, V. Hansen, A. Aldahan, G. Possnert, O. C. Lind, \& G. Lujaniene, A review on speciation of iodine-129 in the environmental and biological samples. Analytica Chimica Acta, 632 (2009) 181-196. https://doi.org/10.1016/J.ACA.2008.11.013.

3. A. Ringbom, A. Axelsson, M. Aldener, M. Auer, T. W. Bowyer, T. Fritioff, I. Hoffman, K. Khrustalev, M. Nikkinen, V. Popov, Y. Popov, K. Ungar, \& G. Wotawa, Radioxenon detections in the CTBT international monitoring system likely related to the announced nuclear test in North Korea on February 12, 2013. Journal of Environmental Radioactivity, 128 (2014) 47-63. https://doi.org/10.1016/J.JENVRAD.2013.10.027.

4. M. B. Kalinowski, A. Axelsson, M. Bean, X. Blanchard, T. W. Bowyer, G. Brachet, S. Hebel, J. I. McIntyre, J. Peters, C. Pistner, M. Raith, A. Ringbom, P. R. J. Saey, C. Schlosser, T. J. Stocki, T. Taffary, \& R. Kurt Ungar, Discrimination of Nuclear Explosions against Civilian Sources Based on Atmospheric Xenon Isotopic Activity Ratios. Pure and Applied Geophysics, 167 (2010) 517-539. https://doi.org/10.1007/s00024-009-0032-1.

5. Y. Sun, C. R. Carrigan, \& Y. Hao, Radioxenon Production and Transport from an Underground Nuclear Detonation to Ground Surface. Pure and Applied Geophysics, 172 (2015) 243-265. https://doi.org/10.1007/s00024-014-0863-2.

6. E. Pili, L. Pannecoucke, S. Guillon, \& D. R. Neuville, Gas-Magma Interactions in Nuclear Cavities and Their Effects on the Xenon Isotope Ratios. CTBT Sci. Technol. Conf. 26-30 June 2017, Vienna, Austria (2017), p. T1.3-P8.

7. B. J. Riley, M. J. Schweiger, D.-S. Kim, W. W. Lukens, B. D. Williams, C. Iovin, C. P. Rodriguez, N. R. Overman, M. E. Bowden, D. R. Dixon, J. V. Crum, J. S. McCloy, \& A. A. Kruger, Iodine solubility in a low-activity waste borosilicate glass at $1000^{\circ} \mathrm{C}$. Journal of Nuclear Materials, 452 (2014) 178-188. https://doi.org/10.1016/j.jnucmat.2014.04.027.

8. M. Fuhrmann, S. Bajt, \& M. A. A. Schoonen, Sorption of iodine on minerals investigated by X-ray absorption near edge structure (XANES) and 125I tracer sorption experiments. Applied Geochemistry, 13 (1998) 127-141. https://doi.org/10.1016/S0883-2927(97)00068-1.

9. B. J. Riley, J. D. Vienna, D. M. Strachan, J. S. McCloy, \& J. L. Jerden, Materials and processes for the effective capture and immobilization of radioiodine: A review. Journal of Nuclear Materials, 470 (2016) 307-326. https://doi.org/10.1016/J.JNUCMAT.2015.11.038.

10. M. I. Ojovan \& W. E. Lee, An introduction to nuclear waste immobilisation, second edition (Elsevier, 2014).

11. M. R. Cicconi, E. Pili, L. Grousset, P. Florian, J.-C. Bouillard, D. Vantelon, \& D. R. Neuville, Iodine dissolution and speciation in glasses: the effect of the glass-forming system fragility. submitted, (n.d.).

12. M. Lenoir, A. Grandjean, Y. Linard, B. Cochain, \& D. R. Neuville, The influence of Si,B substitution and of the nature of network-modifying cations on the properties and structure of borosilicate glasses and melts. Chemical Geology, 256 (2008) 316-325. https://doi.org/10.1016/J.CHEMGEO.2008.07.002.

13. D. Möncke, G. Tricot, A. Winterstein-Beckmann, L. Wondraczek, \& E. I. Kamitsos, On the connectivity of borate tetrahedra in borate and borosilicate glasses. Physics and Chemistry of Glasses-European Journal of Glass Science and Technology Part B, 56 (2015) $203-211$.

14. D. L. Griscom, Borate Glass Structure. In N.J. Pye, L.D., Fréchette, V.D., Kreidl,ed., Borate Glas. (Boston, MA: Springer US, 1978 ), pp. 11-138. https://doi.org/10.1007/978-1-4684-3357-9_2.

15. D. A. McKeown, I. S. Muller, \& I. L. Pegg, Iodine valence and local environments in borosilicate waste glasses using X-ray absorption spectroscopy. Journal of Nuclear Materials, 456 (2015) 182-191. https://doi.org/10.1016/J.JNUCMAT.2014.09.033.

16. C. Le Losq, D. R. Neuville, W. Chen, P. Florian, D. Massiot, Z. Zhou, \& G. N. Greaves, Percolation channels: a universal idea to describe the atomic structure and dynamics of glasses and melts. Scientific Reports, 7 (2017) 16490. https://doi.org/10.1038/s41598-017-16741-3. 